\title{
Emerging Roles of $\gamma$ Aminobutyric Acid (GABA) Gated Channels in Plant Stress Tolerance
}

\author{
Mona Kaspal $^{\dagger}$, Madhuka H. Kanapaddalagamage ${ }^{\dagger}$ and Sunita A. Ramesh * ${ }^{*}$ \\ Transport Physiology and Signalling Group, Biological Sciences, College of Science and Engineering, \\ Flinders University, Bedford Park, SA 5042, Australia; mona.kaspal@flinders.edu.au (M.K.); \\ kana0060@flinders.edu.au (M.H.K.) \\ * Correspondence: sunita.ramesh@flinders.edu.au \\ † These authors equally contributed.
}

\begin{abstract}
The signaling role for $\gamma$-Aminobutyric acid (GABA) has been documented in animals for over seven decades. However, a signaling role for GABA in plants is just beginning to emerge with the discovery of putative GABA binding site/s and GABA regulation of anion channels. In this review, we explore the role of GABA in plant growth and development under abiotic stress, its interactions with other signaling molecules and the probability that there are other anion channels with important roles in stress tolerance that are gated by GABA.
\end{abstract}

Keywords: $\gamma$-aminobutyric acid; aluminium-activated malate transporters; channels; receptors; signalling; GABA metabolism; stress response

Citation: Kaspal, M.;

Kanapaddalagamage, M.H.; Ramesh,

S.A. Emerging Roles of $\gamma$

Aminobutyric Acid (GABA) Gated Channels in Plant Stress Tolerance.

Plants 2021, 10, 2178. https://

doi.org/10.3390/plants10102178

Academic Editor: José

M. Colmenero-Flores

Received: 1 September 2021

Accepted: 4 October 2021

Published: 14 October 2021

Publisher's Note: MDPI stays neutral with regard to jurisdictional claims in published maps and institutional affiliations.

Copyright: (c) 2021 by the authors. Licensee MDPI, Basel, Switzerland. This article is an open access article distributed under the terms and conditions of the Creative Commons Attribution (CC BY) license (https:// creativecommons.org/licenses/by/ $4.0 /)$.

\section{Introduction}

$\gamma$ aminobutyric acid (GABA), a non-protein amino acid, was discovered nearly seven decades ago in potato tubers, followed by its discovery in mammalian brain extracts where it has been shown to be a major inhibitory neurotransmitter [1-3]. Activation of chloride conductance mediated through mammalian $\mathrm{GABA}_{\mathrm{A}}$ receptors results in membrane hyperpolarisation in the central nervous systems, leading to dampening of neuronal firing [4-8]. The activity of GABA receptors in the brain and other organs in mammals has been extensively reviewed [6-9]. In plants, GABA is ubiquitous and has been documented to occur in many tissues and organs and its role was mainly defined as a metabolite [10-13]. However, in the last three decades, studies have shown that GABA concentrations range from micromolar (low) to millimolar (high) in different tissues, organs, and compartments, suggesting that it may be a signalling molecule, in addition to a metabolite in plants $[11,14]$. The role for GABA as a signalling molecule is further strengthened by the evidence that accumulation of GABA occurs in response to various abiotic and biotic stresses. Binding sites have been detected on cell membranes, GABA gated anion channels are present in plants, and their activity is regulated by agonists and antagonists of GABA receptors in animals [15-19].

The role of GABA in plant growth, development, and stress is well documented in numerous reviews, however the emerging evidence that ion channels implicated in plant stress have potential GABA binding sites and are regulated by it, merits re-examination of roles of GABA in signalling and stress tolerance [13,15,16,18,20-23]. In this review, we will explore various roles of GABA in plant growth and development briefly and focus on the effects of GABA gated ion channels on physiological processes in abiotic stress, explore other ion channels that may potentially be regulated by GABA, and investigate the implications of such regulation on stress tolerance in planta.

\section{GABA Affects Physiological Processes}

Synthesis of GABA occurs in the cytoplasm by decarboxylation of glutamate by glutamate decarboxylase (GAD) in the GABA shunt. The first GAD gene was isolated from 
Petunia and shown to have calmodulin binding domain (CaMBD) in the $C$ terminus [24]. However, not all GAD genes have the CaMBD. In rice (Oryza sativa), OsGAD1 can bind to CaMBD while OsGAD2 does not bind to calmodulin [25]. In apple (Malus $x$ domestica Borkh.), recombinant $M d G A D 1$ and 2 have been shown to bind to calmodulin while MdGAD3 does not bind to it [26]. In tea (Camellia sinensis) leaves, recombinant CsGAD1 and 2 expressed in E. coli convert glutamate to GABA while CsGAD3 showed no activity [27]. CsGAD1 has calmodulin regulated autoinhibitory domain while CsGAD2 and 3 have calmodulin independent autoinhibitory domain. Further, the expression of CsGAD2 was upregulated by mechanical damage caused by picking tea leaves [27].

It has been well documented that GABA can improve or inhibit plant growth and development [28]. In duckweed (Lemna minor L.), the addition of $5 \mathrm{mM} \mathrm{GABA}$ to the nutrient solution caused a two-fold increase in plant growth than the nutrient solution alone [18,29]. Gradients of GABA in the stigma and style are important for proper growth of the pollen tube to reach the ovary, impaired gradients affect fertilisation [30]. Studies in Arabidopsis and Brassica napus suggest a possible role for GABA in regulating nitrate uptake and affect nodule formation in Medicago [31-36]. GABA is involved in regulating leaf senescence and studies suggest that fluctuations in endogenous GABA levels may be regulated or regulate the plant circadian clock [37-39]. Disruption of GABA transaminase (GABA-T) severely impaired cell elongation in Arabidopsis pollen tubes, primary roots, and hypocotyls [30,40,41]. Similarly, overexpression of a Petunia GAD gene (C-terminal calmodulin binding domain removed) in tobacco resulted in increased concentrations of GABA over the wild type and caused slow growth, increased branching and shorter cortical parenchyma [28]. Higher levels of reactive oxygen species (ROS) were observed in Arabidopsis when the succinic semialdehyde dehydrogenase (SSADH) gene was disrupted [12].

Multiple abiotic stresses increase endogenous GABA concentrations in the tissues and, as exogenous application of GABA mimics the effects of stress on growth and development, it provides an easy method to investigate its role in plants [42]. The speed and rate of stress induced GABA accumulation varies from seconds to days and from 10 to 1000 -fold in different plant species - reviewed in these references [43-55]. Among the abiotic stresses, salinity and drought have been widely studied in numerous plant species including Arabidopsis, barley, rice, Medicago, tobacco, soybean and Populus [39,40,44,47,49,56,57]. In maize seedlings exposed to salt $(150 \mathrm{mM} \mathrm{NaCl})$, application of GABA $(0.5 \mathrm{mM})$ resulted in improved growth, alleviated damage to cell membranes, increased soluble sugars and proline accumulation, and reduced water loss [58]. Exposure to $150 \mathrm{mM} \mathrm{NaCl}$ led to GABA accumulation and inhibition of primary root growth (17\%) in Arabidopsis GABA-T mutant [59] while in Arabidopsis gad1/gad2 mutants decrease in GABA synthesis resulted in increased stomatal conductance rendering the plants more sensitive to drought [55]. A triple mutant gad1/gad2 X pop 2-5 was observed to have increased endogenous GABA content with stomatal conductance restored to wild type levels and was less sensitive to drought [55]. Under hypoxia, exogenous application of GABA in Prunus genotype, sensitive to waterlogging, led to increased stomatal conductance, lower ROS production, and less leaf lesions when compared to the tolerant genotype [60]. In sunflower, GABA $(2 \mathrm{mg} / \mathrm{L})$ treatment increased chlorophyll and sugar content, resulting in the upregulation of antioxidant enzymes during heat and drought stress [61]. The application of GABA ( $50 \mathrm{mg} / \mathrm{L}$ ) to wheat seedlings limited ROS production, increased accumulation of soluble protein and maintained amino acid homeostasis, while the application of GABA $(1 \mathrm{mM})$ to heat stressed mung beans improved reproductive function [62,63].

Cold stress can severely effect plant growth and yield and several studies have shown that accumulation of GABA, proline, and polyamines contribute to chilling tolerance [64]. Cold sensitive tomato plants treated with GABA $(50 \mathrm{mM})$ showed improved plant growth by regulating antioxidant levels and cell expansion [65]. Treatment of fruit with GABA before cold storage has been shown to improve chilling induced injuries and improve shelf-life [66-70]. All these studies indicate that GABA has an important role to play not only in normal growth and development but also during the diverse abiotic stresses that 
plants encounter, stresses that are set to increase in frequency due to adverse growing conditions resulting from global climate change.

\section{GABA Regulation of Gene Expression}

Studies have documented GABA regulation of gene expression and possible interactions with other signalling and stress response pathways [71,72]. In Arabidopsis, GABA downregulates the expression of family of 14-3-3 genes [71]. This family of genes encode ubiquitous regulatory proteins that regulate target proteins in a phosphorylation dependent manner and have important roles in regulating carbon and nitrogen metabolism in plants. The 14-3-3 proteins interact with calcium dependent protein kinases, sucrose nonfermenting -1- related protein kinase 1, other protein kinases, and nitrate reductase [71]. GABA represses the transcription of most of the family of 14-3-3 genes in the presence of high external calcium and interestingly this response is dependent on intact ethylene and abscisic acid signalling pathways suggesting a possible cross talk [71].

In Brassica napus, exogenous GABA $(100 \mu \mathrm{M})$ application to the roots upregulated the mRNA expression of nitrate transporter $B n N r t 2$ but did not have a significant effect on nitrate influx [31]. In rice seedlings treated with either 50 or $100 \mu \mathrm{g} / \mathrm{mL}$ of GABA, accumulation of arsenic was decreased and at lower concentration induced the expression of Lsi-1 transporter in the roots [73]. Interestingly the addition of GABA $(50 \mu \mathrm{g} / \mathrm{mL})$ along with arsenic downregulated the expression Lsi-1 gene in the roots, whereas the expression of Lsi-2 was downregulated by addition of $100 \mu \mathrm{g} / \mathrm{mL}$ GABA along with arsenic. The expression of various antioxidant enzymes such as catalase, POD, SOD, and MDHAR were higher in GABA treated plants [73].

Under salinity, the leaves of Agrostis stolonifera (creeping bentgrass) had lower expression of inorganic pyrophosphatase (AsPPa2), sodium hydrogen exchanger (AsNHX1, AsNHX4), salt overly sensitive (AsSOS1), and sodium transporter (AsHKT4) genes while roots showed increased expression of AsNHX1, AsNHX2, AsNHX4, AsNHX6, AsNHX8, and $A s S O S 20$ in GABA treated plants compared to the control plants [74]. GABA-treated plants also exhibited significantly higher AsSOS1 expression. All these genes are involved in $\mathrm{Na}^{+}$transport, efflux, and compartmentation.

Although it is known that salt stress limits water uptake mediated by aquaporins $(A Q P \mathrm{~s})$, and GABA concentrations increase under salinity, it is unclear whether GABA is involved in the regulation of activity of aquaporins (Figure 1). Exogenous GABA application in creeping bentgrass alleviated drought-induced decline in relative water content and water use efficiency and increased organic acids in leaves [75]. GABA application significantly downregulated transcript levels of aquaporins TIP1-1, TIP1-2, TIP2-1, PIP1-1, and NIP1-4 under salt stress [74].

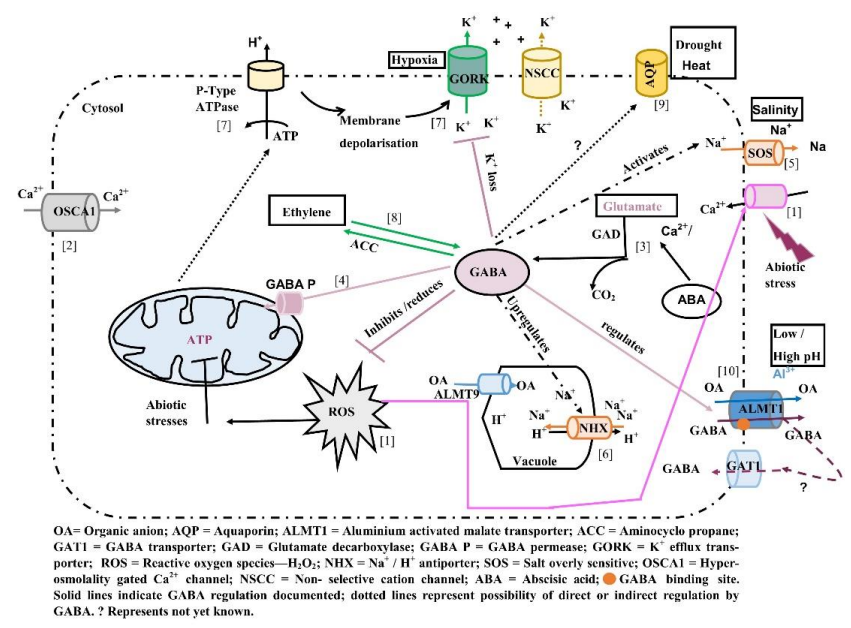

Figure 1. Summary of known ion channels and transporters whose activity is regulated by GABA and potential candidates (ion channels) whose activity may be regulated by GABA under various abiotic stresses (for description, see text). 


\section{GABA Is Involved in Cross Talk with Other Stress Signalling Pathways}

Phytohormones such as auxins, cytokinins, abscisic acid, and ethylene interact with GABA and may have a role in stress tolerance [72]. Both indole acetic acid (IAA, $10 \mu \mathrm{M}$ ) and abscisic acid (ABA, $100 \mu \mathrm{M})$ have been shown to induce the transcription of Arabidopsis Aluminium Activated Malate Transporter AtALMT1, which is essential for aluminium $\left(\mathrm{Al}^{3+}\right)$ tolerance [76]. GABA $(100 \mu \mathrm{M})$ can regulate the malate stimulated currents in AtALMT1 expressed in Xenopus oocytes [16].

Transcriptomic analysis of Arabidopsis seedlings grown on GABA $(10 \mu \mathrm{M})$ revealed the downregulation of a number of genes encoding lipid transfer proteins, peroxidases, and cell wall proteins such as arabinogalactans [77]. Interestingly, application of cytokinin (6-benzyl adenine) to Arabidopsis seedlings downregulated the same set of genes affected by GABA treatment. Tobacco plants transformed with iso-pentyl transferase (ipt) driven by senescence activated promoter (SAG) showed increased cytokinin content and accumulation of proline, methionine, and GABA when exposed to increasing levels of zinc in the soil [78].

Abscisic acid (ABA) is a critical hormone involved in plant growth and development and regulates plant responses to stress [79]. The ABA levels change in response to various abiotic stresses (e.g., drought, heat, salinity) and play crucial roles in stomatal closure mediated by signalling cascades involving pyrabacin resistance 1(PYL)/ PYR1-like regulatory components of ABA receptors (RCAR), type $2 \mathrm{C}$ protein phosphatases (PP2Cs), sucrose non-fermenting 1-related subfamily $2(S n R K 2 \mathrm{~s})$ and protein kinase open stomata 1 (OST1) [80]. Arabidopsis plants deficient in GABA synthesis showed deformed stomata and impaired stomatal closure [55]. Recently, it has been reported that guard cell GABA production is essential for reducing stomatal opening and transpirational water loss by negative regulation of tonoplast localised At ALMT9 in Arabidopsis [81]. GABA (2 mM) was observed to inhibit ABA $(2.5 \mu \mathrm{M})$ induced stomatal closure at low concentrations and in mutant plants impaired in GABA synthesis (gad2-1) and ALMT9 (almt9), ABA could induce stomatal closure to wild type levels [81]. Taken together, these findings suggest that there is a cross talk between GABA regulated ALMT9 and ABA in mediating stomatal closure under drought stress (Figure 1).

Levels of ethylene, another phytohormone are regulated in response to stress $[82,83]$. Application of increasing concentrations of GABA $(0-300 \mathrm{mM})$ promoted ethylene production (14 fold) in sunflower seedlings by upregulation of the expression of 1-aminocyclopropane-1-carboxylic acid (ACC synthase) [84]. Many stresses such as wounding, hypoxia, cold and heat under which plants evolve more ethylene, also result in GABA accumulation. Studies suggest that during wounding or mechanical damage, GABA accumulation occurs within $30 \mathrm{~s}$ and precedes ethylene production which occurs after $30 \mathrm{~min}$ [84]. Malate efflux from tobacco BY2 cells expressing wheat ALMT1 was inhibited when cells exposed to $\mathrm{Al}^{3+}$ were treated with ethylene donor Ethrel [85]. Further, ethylene evolution and malate efflux from root tips increased in $\mathrm{Al}^{3+}$ tolerant near isogenic of wheat ET8 but malate efflux was inhibited on exposure to ethylene precursor ACC [85].

Many of the abiotic stresses under which the levels of phytohormones change also result in changes in GABA levels suggesting that there may be interactions between multiple players and pathways that mediate plant stress tolerance.

\section{GABA Gated Channels}

Many studies have well documented the role of GABA as a primary metabolite, but its signalling role is an emerging area of research in plants $[11,13,15,16,30]$. For a molecule to be classified as a signal, it needs to be present in very low concentrations, bind to a receptor, and elicit a specific cellular response. The fact that GABA occurs in high concentrations and is present in almost every part of the plant would argue against it being a signal [11]. Molecules that lead to changes in membrane potential in response to a triggering event are key cellular signals and, as GABA modifies membrane potential and is essential for plant growth, it has a potential signalling role in planta [16]. Early evidence for a signalling role 
for GABA was observed in bacterial quorum sensing [86]. Numerous other studies reported involvement of GABA in regulation of stomatal apertures under drought, plant-insect communication, plant-bacterial interactions, regulation of ROS levels and modulation of growth and development by exogenous application leading to the speculation that it has a signalling role in plants $[14,22]$. The discovery of family of plant glutamate receptors (GLRs) led to the assumption that GABA might function as a signal via GLRs $[87,88]$. However, no GLR to date has been shown to interact with GABA.

Evidence for GABA regulation of transporters involved in tolerance to aluminium toxicity, salinity, and hypoxia is just beginning to emerge (Figure 1). (1) Abiotic stresses such as salinity, cold, heat, and drought can lead to increase in cytosolic $\mathrm{Ca}^{2+}$ levels via calcium influx mediated by $\mathrm{Ca}^{2+}$ channels and the production of reactive oxygen species (ROS). Increasing cytosolic $\mathrm{Ca}^{2+}$ levels activate ROS generating enzymes leading to ROS production. However, generation of ROS during stress may also activate $\mathrm{Ca}^{2+}$ uptake channels leading to increase in cytosolic calcium levels [23,89,90]. (2) OSCA1 has been identified as an osmosensor localised to the plasma membrane involved in increases in internal calcium in response to osmotic stress [91]. (3) Increases in internal $\mathrm{Ca}^{2+}$ lead to $\mathrm{Ca}^{2+}$ binding to calmodulin binding site (CaMBD) on glutamate decarboxylase $(G A D)$ leading to conversion of glutamate to GABA. Under stress, key enzymes of the tricarboxylic acid cycle (TCA) are inhibited. (4) Increased GABA produced in the cytosol is transported to the mitochondria via GABA permease (GABA P) and provides anaplerotic succinate to maintain energy production via ATP synthesis [12,92]. $(5,6)$ GABA may be involved in modulating the activity of SOS genes involved in mediating $\mathrm{Na}^{+}$efflux and NHX antiporters in sequestering excess $\mathrm{Na}^{+}$into the vacuole [74]. (7) Accumulation of GABA under stress reduced $\mathrm{Na}^{+}$uptake, ROS concentrations, induced the activation of $\mathrm{H}^{+}$ ATPase and decreased $\mathrm{K}^{+}$loss [23,75,93-95]. (8) Exogenous GABA application influences ethylene biosynthesis via changes in transcript abundance of ACC synthase and ACO (ACC oxidase), key enzymes in the biosynthetic pathway $[84,94]$. (9) The expression of some aquaporin genes has been observed to change in response to changing GABA levels in the cells under stress, however whether these genes are regulated by GABA requires further investigation [74]. (10) Recently, GABA has been shown to regulate the activity of ALMT family of proteins influencing responses to stresses such as drought, acid, and alkaline soils $[16,84,96]$. Thus, accumulation of GABA under stress may influence the expression and activity of key enzymes and ion channels and play a role in mediating plant stress tolerance.

The recent discovery of a putative GABA binding site (12 amino acids) on a family of plant anion channels-ALMTs with homology to the binding site on the mammalian $\mathrm{GABA}_{\mathrm{A}}$ receptor has provided the first experimental evidence towards establishing GABA as a signalling molecule [16]. This discovery has been referred to as the discovery of 'GABA receptor' in plants [97]. The ALMT proteins mainly encode voltage gated anion channels but also include rapid or quick acting anion channels [96,98-100]. The ALMT family is multigenic and members of this family are involved in processes such as aluminium tolerance (TaALMT1), mineral nutrition and ion homeostasis (ZmALMT1), vacuolar homeostasis (AtALMT9), stomatal movement (AtALMT12), and solubilisation of soil nutrients such as phosphate (ZmALMT2) [101-105].

Opening of ALMT anion channels leads to release of anions (malate) and depolarisation of the membrane [106]. The ALMTs can also be transactivated by anions such as sulphate on the efflux side of the channel protein [16,98]. Although both ALMTs and $\mathrm{GABA}_{\mathrm{A}}$ receptors encode anion channels, they share little similarity in the full-length protein sequences. The putative GABA binding site on the ALMTs is a 12 amino acid stretch occurring at the end of sixth transmembrane domain and towards the $C$ terminus of the proteins [14,16]. GABA regulated anion (malate) efflux mediated by the ALMTs is sensitive to low micromolar concentrations of GABA [16]. Further, the activation of wheat ALMT1 (TaALMT1) leads to a negative correlation between anion (malate) efflux and endogenous GABA concentrations in heterologous expression systems in planta. Aromatic amino acids 
phenylalanine $(\mathrm{F})$ and tyrosine $(\mathrm{Y})$ in the putative GABA binding site are important for GABA regulation and mutation of these amino acids to cysteine effects GABA affinity and increases the $\mathrm{EC}_{50}$ from $3.4 \mu \mathrm{M}$ to $1.8 \mathrm{mM}$ in the wheat $A L M T 1$ and from $6.0 \mu \mathrm{M}$ to $380 \mu \mathrm{M}$ in the Vitis ALMT9 $[14,16]$.

Interestingly the correlation between anion efflux and GABA concentrations is uncoupled in TaALMT1 when phenylalanine is mutated to cysteine (F213C) [16,107]. Decrease in endogenous GABA concentrations is a result of GABA efflux mediated by TaALMT1 and ALMTs can both transport and efflux GABA [107]. Patch clamping of TaALMT1 in Xenopus oocytes suggests that GABA inhibits malate currents from the cyto-plasmic side [108]. The ability of ALMTs to transport GABA and be regulated by it involves a fine balance between the need for anion efflux under adverse conditions such as aluminium toxicity and the necessity to regulate such flux to prevent carbon and nitrogen loss. It is unknown whether the transport of anions such as malate and GABA via ALMTs occur due to a switch between anion conducting or GABA conducting states in the same pore or due to conformational changes occurring due to the binding of GABA to the protein.

Recently, it has been shown that GABA regulates the tonoplast localised Arabidopsis AtALMT9 and plasma membrane localised AtALMT12 in the guard cells and modulates the opening and closing of stomata under drought [81]. This opens avenues for further research into cross talk between signalling pathways that are involved in regulation of stomatal apertures in response to various abiotic stresses and whether there are other ALMTs that may be involved in mediating such responses. The discovery of GABA-gated channels provides compelling evidence that GABA is a plant signalling molecule and these putative plant 'GABA receptors' are involved in translating changes in metabolic status into physiological responses during stress [109].

It is well known that depolarisation activated outward rectifying potassium $\left(\mathrm{K}^{+}\right)$efflux channels (GORKs) from Arabidopsis have an important role in stress induced $\mathrm{K}^{+}$efflux from plants cells [110]. These voltage gated channels are expressed in guard cells and are involved in stomatal closure [111,112]. Recently it was shown that both GORK channels from plants and the mammalian outward rectifying $\mathrm{K}^{+}$efflux channels (ORKs) have a putative GABA binding motif that is similar to that identified in ALMT proteins [113]. In Arabidopsis root epidermis, GABA induced $\mathrm{K}^{+}$efflux was markedly different between wild type (Col0) and gork1-1 mutant impaired in $\mathrm{K}^{+}$efflux when measured via the Microelectrode Ion Flux Estimation (MIFE) technique [113]. The authors suggest that GABA regulation of $\mathrm{K}^{+}$efflux via GORKs is important for stress tolerance. Further, greater salinity tolerance of Arabidopsis mutant pop2-5 (GABA-transaminase knock out) that is impaired in GABA catabolism has been in part attributed to higher concentrations of GABA, stress-induced activation of $\mathrm{H}^{+}$ATPase leading to efficient maintenance of transmembrane electrical potential, and reduced stress induced $\mathrm{K}^{+}$leak mediated by GORKs from the roots [93].

Hypoxia induced accumulation of GABA is large and has been documented in number of plant species [43,63]. In a study with Arabidopsis wild type (Col0) and mutants impaired in GABA synthesis (gad1/2), plants with less GABA accumulation were observed to be less tolerant to hypoxia, had lower fresh weight and chlorophyll content compared to wild type plants [23]. Hypoxia induces $\operatorname{ROS}\left(\mathrm{H}_{2} \mathrm{O}_{2}\right)$ accumulation leading to loss of cell viability and, interestingly, in this study it has been shown that higher concentrations of GABA in the pop2-5 mutants resulted in lower levels of $\mathrm{H}_{2} \mathrm{O}_{2}$ when compared to wild type or gad1/2 plants. Waterlogging leads to reduced oxygen availability affecting $\mathrm{H}^{+}$-ATPase pump activity resulting in membrane depolarisation and $\mathrm{K}^{+}$loss via GORK channels [23]. Increased GABA shunt activity leading to accumulation of GABA under hypoxia may restore membrane potential by regulation of $\mathrm{H}^{+}$-ATPase activity as synthesis of GABA consumes a proton $\left(\mathrm{H}^{+}\right)$and raises $\mathrm{pH}$ [114]. Restoration of negative membrane potential is essential to prevent stress induced $\mathrm{K}^{+}$efflux and, thus, increased GABA levels may regulate $\mathrm{K}^{+}$loss via the GORK channels $[23,115]$.

Transporters involved in sodium $\left(\mathrm{Na}^{+}\right)$transport and efflux are important for maintaining ion homeostasis under salt stress. Transcripts levels of numerous genes involved 
in $\mathrm{Na}^{+}$transport and compartmentalisation were observed to change in GABA treated A. stolonifera under salinity, however, this study did not provide any evidence for GABA regulation of genes encoding these transporters or channels [74]. It would be interesting to express some of these transporters/channels in heterologous expression systems and investigate if they are regulated by exogenous GABA and whether their regulation by GABA contributes to salinity tolerance in plants. GABA accumulation occurs under both drought and salinity, and it is known that salt stress limits water uptake. However, there is no evidence yet whether GABA is involved in the regulation of aquaporins that mediate water uptake.

\section{Conclusions}

Emerging evidence indicates that GABA may have a dual role, namely that of a metabolite and a signal under stress. ALMTs are the first plant proteins that have been shown to have a putative GABA binding site. GABA regulates malate efflux mediated by $A L M T$ s in response to acidic and alkaline stresses and modulates stomatal opening to improve water use efficiency under drought stress. As GABA concentrations increase when plants are exposed to diverse abiotic stresses, it is highly likely that other transport proteins or channels (e.g., aquaporins) involved in abiotic stresses (e.g., salinity, drought) may be regulated by GABA either directly or indirectly (Figure 1). Not much is known about how GABA binds and interacts with proteins (e.g., whether the generated signal is transient or sustained) or the molecular basis of GABA regulation of transporters and ion channels that help plants tolerate and thrive under adverse conditions. No functional characterisation of recently identified GABA motif in GORK channels has been carried out yet. Mutational studies could pinpoint residues essential for GABA binding and affinity of GABA for binding to these residues. These knowledge gaps need to be bridged to enhance our understanding of the structural and molecular basis of stress-induced GABA regulation of various proteins to improve plant productivity for future food security.

Author Contributions: M.K. and M.H.K. reviewed the literature and drafted sections of the manuscript. S.A.R. reviewed and edited the manuscript. All authors had intellectual input and commented on the manuscript. All authors have read and agreed to the published version of the manuscript.

Funding: S.A.R. acknowledges funding support from the College of Science and Engineering, Flinders University.

Conflicts of Interest: The authors declare no conflict of interest.

\section{References}

1. Steward, F.C. $\gamma$-aminobutyric acid, a constituent of the potato tuber? Science 1949, 110, 439-440.

2. Roberts, E.; Frankel, S. $\gamma$-aminobutyric acid in brain: Its formation from glutamic acid. J. Biol. Chem. 1950, 187, 55-63. [CrossRef]

3. Awapara, J.; Landua, A.J.; Fuerst, R.; Seale, B. Free $\gamma$-aminobutyric acid in brain. J. Biol. Chem. 1950, 187, 35-39. [CrossRef]

4. Watanabe, M.; Fukuda, A. Development and regulation of chloride homeostasis in the central nervous system. Front. Cell. Neurosci. 2015, 9, 14. [CrossRef]

5. Ben-Ari, Y.; Gaiarsa, J.-L.; Tyzio, R.; Khazipov, R. GABA: A pioneer transmitter that excites immature neurons and generates primitive oscillations. Physiol. Rev. 2007, 87, 1215-1284. [CrossRef]

6. Li, K.; Xu, E. The role and the mechanism of $\gamma$-aminobutyric acid during central nervous system development. Neurosci. Bull. 2008, 24, 195. [CrossRef]

7. Erdö, S.L.; Wolff, J.R. $\gamma$-Aminobutyric Acid Outside the Mammalian Brain. J. Neurochem. 1990, 54, 363-372. [CrossRef]

8. Barragan, A.; Weidner, J.M.; Jin, Z.; Korpi, E.; Birnir, B. GABAergic signalling in the immune system. Acta Physiol. 2015, 213, 819-827. [CrossRef]

9. Owens, D.F.; Kriegstein, A.R. Is there more to GABA than synaptic inhibition? Nat. Rev. Neurosci. 2002, 3, 715-727. [CrossRef]

10. Narayan, V.S.; Nair, P. Metabolism, enzymology and possible roles of 4-aminobutyrate in higher plants. Phytochemistry 1990, 29, 367-375. [CrossRef]

11. Shelp, B.J.; Bown, A.W.; McLean, M.D. Metabolism and functions of gamma-aminobutyric acid. Trends Plant Sci. 1999, 4, 446-452. [CrossRef]

12. Bouche, N.; Fait, A.; Bouchez, D.; Moller, S.G.; Fromm, H. Mitochondrial succinic-semialdehyde dehydrogenase of the gammaaminobutyrate shunt is required to restrict levels of reactive oxygen intermediates in plants. Proc. Natl. Acad. Sci. USA 2003, 100, 6843-6848. [CrossRef] 
13. Bouche, N.; Fromm, H. GABA in plants: Just a metabolite? Trends Plant Sci. 2004, 9, 110-115. [CrossRef] [PubMed]

14. Ramesh, S.A.; Tyerman, S.D.; Gilliham, M.; Xu, B. Gamma-Aminobutyric acid (GABA) signalling in plants. Cell. Mol. Life Sci. 2017, 74, 1577-1603. [CrossRef] [PubMed]

15. Bown, A.; Shelp, B. The metabolism and functions of -aminobutyric acid. Plant Physiol. Biochem. 1997, 115, 1-5. [CrossRef]

16. Ramesh, S.A.; Tyerman, S.D.; Xu, B.; Bose, J.; Kaur, S.; Conn, V.; Domingos, P.; Ullah, S.; Wege, S.; Shabala, S.; et al. GABA signalling modulates plant growth by directly regulating the activity of plant-specific anion transporters. Nat. Commun. 2015, 6 . [CrossRef]

17. Yue, X.; Gao, X.Q.; Wang, F.; Dong, Y.; Li, X.; Zhang, X.S. Transcriptional evidence for inferred pattern of pollen tube-stigma metabolic coupling during pollination. PLoS ONE 2014, 9, e107046. [CrossRef]

18. Kinnersley, A.M.; Turano, F.J. Gamma aminobutyric acid (GABA) and plant responses to stress. Crit. Rev. Plant Sci. 2000, 19, 479-509. [CrossRef]

19. Kinnersley, A.M. Physiological evidence for GABA receptors in plants. Plant Biol. 1999, 1999, 153.

20. Bouche, N.; Lacombe, B.; Fromm, H. GABA signaling: A conserved and ubiquitous mechanism. Trends Cell Biol. 2003, 13, 607-610. [CrossRef]

21. Shelp, B.J.; Bozzo, G.G.; Trobacher, C.P.; Zarei, A.; Deyman, K.L.; Brikis, C.J. Hypothesis/review: Contribution of putrescine to 4-aminobutyrate (GABA) production in response to abiotic stress. Plant Sci. 2012, 193-194, 130-135. [CrossRef]

22. Bown, A.W.; Shelp, B.J. Plant GABA: Not just a metabolite. Trends Plant Sci. 2016, 21, 811-813. [CrossRef]

23. Wu, Q.; Su, N.; Huang, X.; Cui, J.; Shabala, L.; Zhou, M.; Yu, M.; Shabala, S. Hypoxia-induced increase in GABA content is essential for restoration of membrane potential and preventing ROS-induced disturbance to ion homeostasis. Plant Commun. 2021, 2, 100188. [CrossRef]

24. Baum, G.; Chen, Y.; Arazi, T.; Takatsuji, H.; Fromm, H. A plant glutamate decarboxylase containing a calmodulin binding domain Cloning, sequence, and functional analysis. J. Biol. Chem. 1993, 268, 19610-19617. [CrossRef]

25. Akama, K.; Akihiro, T.; Kitagawa, M.; Takaiwa, F. Rice (Oryza sativa) contains a novel isoform of glutamate decarboxylase that lacks an authentic calmodulin-binding domain at the C-terminus. Biochim. Et Biophys. Acta (BBA)-Gene Struct. Expr. 2001, 1522, 143-150. [CrossRef]

26. Trobacher, C.P.; Zarei, A.; Liu, J.; Clark, S.M.; Bozzo, G.G.; Shelp, B.J. Calmodulin-dependent and calmodulin-independent glutamate decarboxylases in apple fruit. BMC Plant Biol. 2013, 13, 144. [CrossRef]

27. Mei, X.; Chen, Y.; Zhang, L.; Fu, X.; Wei, Q.; Grierson, D.; Zhou, Y.; Huang, Y.; Dong, F.; Yang, Z. Dual mechanisms regulating glutamate decarboxylases and accumulation of gamma-aminobutyric acid in tea (Camellia sinensis) leaves exposed to multiple stresses. Sci. Rep. 2016, 6, 23685. [CrossRef]

28. Baum, G.; Lev-Yadun, S.; Fridmann, Y.; Arazi, T.; Katsnelson, H.; Zik, M.; Fromm, H. Calmodulin binding to glutamate decarboxylase is required for regulation of glutamate and GABA metabolism and normal development in plants. EMBO J. 1996, 15, 2988-2996. [CrossRef] [PubMed]

29. Kinnersley, A.M.; Lin, F. Receptor modifiers indicate that 4-aminobutyric acid (GABA) is a potential modulator of ion transport in plants. Plant Growth Regul. 2000, 32, 65-76. [CrossRef]

30. Palanivelu, R.; Brass, L.; Edlund, A.F.; Preuss, D. Pollen tube growth and guidance is regulated by POP2, an Arabidopsis gene that controls GABA levels. Cell 2003, 114, 47-59. [CrossRef]

31. Beuve, N.; Rispail, N.; Laine, P.; CLIQUET, J.B.; Ourry, A.; Le Deunff, E. Putative role of $\gamma$-aminobutyric acid (GABA) as a long-distance signal in up-regulation of nitrate uptake in Brassica napus L. Plant Cell Environ. 2004, 27, 1035-1046. [CrossRef]

32. Barbosa, J.M.; Singh, N.K.; Cherry, J.H.; Locy, R.D. GABA increases the rate of nitrate uptake and utilization in Arabidopsis roots. Plant Biol. 2000, 2000, 133.

33. Barbosa, J.M.; Singh, N.K.; Cherry, J.H.; Locy, R.D. Nitrate uptake and utilization is modulated by exogenous gamma-aminobutyric acid in Arabidopsis thaliana seedlings. Plant Physiol. Biochem. 2010, 48, 443-450. [CrossRef]

34. Jin, H.; Dilworth, M.; Glenn, A. 4-Aminobutyrate is not available to bacteroids of cowpea Rhizobium MNF2030 in snake bean nodules. Arch. Microbiol. 1990, 153, 455-462. [CrossRef]

35. Miller, R.; McRae, D.; Joy, K. Glutamate and g-aminobutyrate metabolism in isolated Rhizobium meliloti bacteroids. Mol. Plant-Microbe Interact. 1991, 4, 37-45. [CrossRef]

36. Sulieman, S. Does GABA increase the efficiency of symbiotic N2 fixation in legumes? Plant Signal Behav. 2011, 6, 32-36. [CrossRef]

37. Diaz, C.; Lemaître, T.; Christ, A.; Azzopardi, M.; Kato, Y.; Sato, F.; Morot-Gaudry, J.-F.; Le Dily, F.; Masclaux-Daubresse, C. Nitrogen recycling and remobilization are differentially controlled by leaf senescence and development stage in Arabidopsis under low nitrogen nutrition. Plant Physiol. 2008, 147, 1437-1449. [CrossRef] [PubMed]

38. Allan, W.L.; Shelp, B.J. A potential role for gamma-hydroxybuty rate production in redox homeostasis. Plant Biol. 2006, $2006,219$.

39. Allan, W.L.; Shelp, B.J. Fluctuations of $\gamma$-aminobutyrate, $\gamma$-hydroxybutyrate, and related amino acids in Arabidopsis leaves as a function of the light-dark cycle, leaf age, and N stress. Botany 2006, 84, 1339-1346.

40. Renault, H.; Roussel, V.; El Amrani, A.; Arzel, M.; Renault, D.; Bouchereau, A.; Deleu, C. The Arabidopsis pop2-1 mutant reveals the involvement of GABA transaminase in salt stress tolerance. BMC Plant Biol. 2010, 10, 20. [CrossRef]

41. Renault, H.; El Amrani, A.; Palanivelu, R.; Updegraff, E.P.; Yu, A.; Renou, J.P.; Preuss, D.; Bouchereau, A.; Deleu, C. GABA accumulation causes cell elongation defects and a decrease in expression of genes encoding secreted and cell wall-related proteins in Arabidopsis thaliana. Plant Cell Physiol. 2011, 52, 894-908. [CrossRef] 
42. Michaeli, S.; Fromm, H. Closing the loop on the GABA shunt in plants: Are GABA metabolism and signaling entwined? Front. Plant Sci. 2015, 6, 419. [CrossRef]

43. Saikusa, T.; Horino, T.; Mori, Y. Distribution of free amino acids in the rice kernel and kernel fractions and the effect of water soaking on the distribution. J. Agric. Food Chem. 1994, 42, 1122-1125. [CrossRef]

44. Dluzniewska, P.; Gessler, A.; Kopriva, S.; Strnad, M.; NOVÁK, O.; Dietrich, H.; Rennenberg, H. Exogenous supply of glutamine and active cytokinin to the roots reduces $\mathrm{NO}_{3}$-uptake rates in poplar. Plant Cell Environ. 2006, 29, 1284-1297. [CrossRef]

45. Mazzucotelli, E.; Tartari, A.; Cattivelli, L.; Forlani, G. Metabolism of gamma-aminobutyric acid during cold acclimation and freezing and its relationship to frost tolerance in barley and wheat. J. Exp. Bot. 2006, 57, 3755-3766. [CrossRef]

46. Vannini, C.; Iriti, M.; Bracale, M.; Locatelli, F.; Faoro, F.; Croce, P.; Pirona, R.; Di Maro, A.; Coraggio, I.; Genga, A. The ectopic expression of the rice Osmyb4 gene in Arabidopsis increases tolerance to abiotic, environmental and biotic stresses. Physiol. Mol. Plant Pathol. 2006, 69, 26-42. [CrossRef]

47. Xing, S.G.; Jun, Y.B.; Hau, Z.W.; Liang, L.Y. Higher accumulation of $\gamma$-aminobutyric acid induced by salt stress through stimulating the activity of diamine oxidases in Glycine max (L.) Merr. roots. Plant Physiol. Biochem. 2007, 45, 560-566. [CrossRef] [PubMed]

48. Bor, M.; Seckin, B.; Ozgur, R.; Yılmaz, O.; Ozdemir, F.; Turkan, I. Comparative effects of drought, salt, heavy metal and heat stresses on gamma-aminobutryric acid levels of sesame (Sesamum indicum L.). Acta Physiol. Plant. 2009, 31, 655-659. [CrossRef]

49. Patterson, J.H.; Newbigin, E.; Tester, M.; Bacic, A.; Roessner, U. Metabolic responses to salt stress of barley (Hordeum vulgare L.) cultivars, Sahara and Clipper, which differ in salinity tolerance. J. Exp. Bot. 2009, 60, 4089-4103.

50. Al-Quraan, N.A.; Locy, R.D.; Singh, N.K. Implications of paraquat and hydrogen peroxide-induced oxidative stress treatments on the GABA shunt pathway in Arabidopsis thaliana calmodulin mutants. Plant Biotechnol. Rep. 2011, 5, 225-234. [CrossRef]

51. Akçay, N.; Bor, M.; Karabudak, T.; Özdemir, F.; Türkan, İ. Contribution of Gamma amino butyric acid (GABA) to salt stress responses of Nicotiana sylvestris CMSII mutant and wild type plants. J. Plant Physiol. 2012, 169, 452-458. [CrossRef] [PubMed]

52. Guo, Y.; Yang, R.; Chen, H.; Song, Y.; Gu, Z. Accumulation of $\gamma$-aminobutyric acid in germinated soybean (Glycine max L.) in relation to glutamate decarboxylase and diamine oxidase activity induced by additives under hypoxia. Eur. Food Res. Technol. 2012, 234, 679-687. [CrossRef]

53. Vergara, R.; Parada, F.; Rubio, S.; Pérez, F.J. Hypoxia induces $\mathrm{H}_{2} \mathrm{O}_{2}$ production and activates antioxidant defence system in grapevine buds through mediation of $\mathrm{H}_{2} \mathrm{O}_{2}$ and ethylene. J. Exp. Bot. 2012, 63, 4123-4131. [CrossRef] [PubMed]

54. Nayyar, H.; Kaur, R.; Kaur, S.; Singh, R. $\gamma$-Aminobutyric acid (GABA) imparts partial protection from heat stress injury to rice seedlings by improving leaf turgor and upregulating osmoprotectants and antioxidants. J. Plant Growth Regul. 2014, 33, 408-419. [CrossRef]

55. Mekonnen, D.W.; Flügge, U.-I.; Ludewig, F. Gamma-aminobutyric acid depletion affects stomata closure and drought tolerance of Arabidopsis thaliana. Plant Sci. 2016, 245, 25-34. [CrossRef]

56. Fougere, F.; Le Rudulier, D.; Streeter, J.G. Effects of salt stress on amino acid, organic acid, and carbohydrate composition of roots, bacteroids, and cytosol of alfalfa (Medicago sativa L.). Plant Physiol. 1991, 96, 1228-1236. [CrossRef]

57. Zhang, J.; Zhang, Y.; Du, Y.; Chen, S.; Tang, H. Dynamic metabonomic responses of tobacco (Nicotiana tabacum) plants to salt stress. J. Proteome Res. 2011, 10, 1904-1914. [CrossRef]

58. Wang, Y.; Gu, W.; Meng, Y.; Xie, T.; Li, L.; Li, J.; Wei, S. $\gamma$-Aminobutyric acid imparts partial protection from salt stress injury to maize seedlings by improving photosynthesis and upregulating osmoprotectants and antioxidants. Sci. Rep. 2017, 7, 1-13. [CrossRef] [PubMed]

59. Sheteiwy, M.S.; Shao, H.; Qi, W.; Hamoud, Y.A.; Shaghaleh, H.; Khan, N.U.; Yang, R.; Tang, B. GABA-alleviated oxidative injury induced by salinity, osmotic stress and their combination by regulating cellular and molecular signals in rice. Int. J. Mol. Sci. 2019, 20, 5709. [CrossRef]

60. Salvatierra, A.; Pimentel, P.; Almada, R.; Hinrichsen, P. Exogenous GABA application transiently improves the tolerance to root hypoxia on a sensitive genotype of Prunus rootstock. Environ. Exp. Bot. 2016, 125, 52-66. [CrossRef]

61. Abdel Razik, E.S.; Alharbi, B.M.; Pirzadah, T.B.; Alnusairi, G.S.; Soliman, M.H.; Hakeem, K.R. $\gamma$-Aminobutyric acid (GABA) mitigates drought and heat stress in sunflower (Helianthus annuus L.) by regulating its physiological, biochemical and molecular pathways. Physiol. Plant. 2021, 172, 505-527. [CrossRef]

62. Wang, X.; Wang, X.; Peng, C.; Shi, H.; Yang, J.; He, M.; Zhang, M.; Zhou, Y.; Duan, L. Exogenous Gamma-aminobutyric Acid Coordinates Active Oxygen and Amino Acid Homeostasis to Enhance Heat Tolerance in Wheat Seedlings. J. Plant Growth Regul. 2021. [CrossRef]

63. Priya, M.; Sharma, L.; Kaur, R.; Bindumadhava, H.; Nair, R.M.; Siddique, K.; Nayyar, H. GABA ( $\gamma$-aminobutyric acid), as a thermo-protectant, to improve the reproductive function of heat-stressed mungbean plants. Sci. Rep. 2019, 9, 7788. [CrossRef] [PubMed]

64. Wang, Y.; Xiong, F.; Nong, S.; Liao, J.; Xing, A.; Shen, Q.; Ma, Y.; Fang, W.; Zhu, X. Effects of nitric oxide on the GABA, polyamines, and proline in tea (Camellia sinensis) roots under cold stress. Sci. Rep. 2020, 10, 12240. [CrossRef]

65. Liu, T.; Jiao, X.; Yang, S.; Zhang, Z.; Ye, X.; Li, J.; Qi, H.; Hu, X. Crosstalk between GABA and ALA to improve antioxidation and cell expansion of tomato seedling under cold stress. Environ. Exp. Bot. 2020, 180, 104228. [CrossRef]

66. Li, J.; Zhou, X.; Wei, B.; Cheng, S.; Zhou, Q.; Ji, S. GABA application improves the mitochondrial antioxidant system and reduces peel browning in 'Nanguo' pears after removal from cold storage. Food Chem. 2019, 297, 124903. [CrossRef] 
67. Wang, Y.; Luo, Z.; Huang, X.; Yang, K.; Gao, S.; Du, R. Effect of exogenous $\gamma$-aminobutyric acid (GABA) treatment on chilling injury and antioxidant capacity in banana peel. Sci. Hortic. 2014, 168, 132-137. [CrossRef]

68. Sheng, L.; Shen, D.; Luo, Y.; Sun, X.; Wang, J.; Luo, T.; Zeng, Y.; Xu, J.; Deng, X.; Cheng, Y. Exogenous $\gamma$-aminobutyric acid treatment affects citrate and amino acid accumulation to improve fruit quality and storage performance of postharvest citrus fruit. Food Chem. 2017, 216, 138-145. [CrossRef] [PubMed]

69. Malekzadeh, P.; Khosravi-Nejad, F.; Hatamnia, A.A.; Mehr, R.S. Impact of postharvest exogenous $\gamma$-aminobutyric acid treatment on cucumber fruit in response to chilling tolerance. Physiol. Mol. Biol. Plants 2017, 23, 827-836. [CrossRef]

70. Aghdam, M.S.; Razavi, F.; Karamneghad, F. Maintaining the postharvest nutritional quality of peach fruits by $\gamma$-Aminobutyric acid. Iran. J. Plant Physiol. 2016, 5, 1457-1463.

71. Lancien, M.; Roberts, M.R. Regulation of Arabidopsis thaliana 14-3-3 gene expression by gamma-aminobutyric acid. Plant Cell Environ. 2006, 29, 1430-1436. [CrossRef] [PubMed]

72. Podlešáková, K.; Ugena, L.; Spíchal, L.; Doležal, K.; De Diego, N. Phytohormones and polyamines regulate plant stress responses by altering GABA pathway. New Biotechnol. 2019, 48, 53-65. [CrossRef] [PubMed]

73. Kumar, N.; Dubey, A.K.; Upadhyay, A.K.; Gautam, A.; Ranjan, R.; Srikishna, S.; Sahu, N.; Behera, S.K.; Mallick, S. GABA accretion reduces Lsi-1 and Lsi-2 gene expressions and modulates physiological responses in Oryza sativa to provide tolerance towards arsenic. Sci. Rep. 2017, 7, 8786. [CrossRef] [PubMed]

74. Li, Z.; Cheng, B.; Zeng, W.; Zhang, X.; Peng, Y. Proteomic and Metabolomic Profilings Reveal Crucial Functions of $\gamma$-Aminobutyric Acid in Regulating Ionic, Water, and Metabolic Homeostasis in Creeping Bentgrass under Salt Stress. J. Proteome Res. 2020, 19, 769-780. [CrossRef]

75. Li, Z.; Huang, T.; Tang, M.; Cheng, B.; Peng, Y.; Zhang, X. iTRAQ-based proteomics reveals key role of $\gamma$-aminobutyric acid (GABA) in regulating drought tolerance in perennial creeping bentgrass (Agrostis stolonifera). Plant Physiol. Biochem. 2019, 145, 216-226. [CrossRef]

76. Kobayashi, Y.; Kobayashi, Y.; Sugimoto, M.; Lakshmanan, V.; Iuchi, S.; Kobayashi, M.; Bais, H.P.; Koyama, H. Characterization of the complex regulation of AtALMT1 expression in response to phytohormones and other inducers. Plant Physiol. 2013, 162, 732-740. [CrossRef]

77. Roberts, M.R. Does GABA Act as a Signal in Plants? Hints from Molecular Studies: Hints from Molecular Studies. Plant Signal. Behav. 2007, 2, 408-409. [CrossRef]

78. Pavlíková, D.; Zemanová, V.; Procházková, D.; Pavlík, M.; Száková, J.; Wilhelmová, N. The long-term effect of zinc soil contamination on selected free amino acids playing an important role in plant adaptation to stress and senescence. Ecotoxicol. Environ. Saf. 2014, 100, 166-170. [CrossRef]

79. Tuteja, N. Abscisic acid and abiotic stress signaling. Plant Signal. Behav. 2007, 2, 135-138. [CrossRef]

80. Dittrich, M.; Mueller, H.M.; Bauer, H.; Peirats-Llobet, M.; Rodriguez, P.L.; Geilfus, C.-M.; Carpentier, S.C.; Al Rasheid, K.A.; Kollist, H.; Merilo, E. The role of Arabidopsis ABA receptors from the PYR/PYL/RCAR family in stomatal acclimation and closure signal integration. Nat. Plants 2019, 5, 1002-1011.

81. Xu, B.; Long, Y.; Feng, X.; Zhu, X.; Sai, N.; Chirkova, L.; Betts, A.; Herrmann, J.; Edwards, E.J.; Okamoto, M. GABA signalling modulates stomatal opening to enhance plant water use efficiency and drought resilience. Nat. Commun. 2021, 12, 1952. [CrossRef]

82. Abeles, F.B.; Morgan, P.W.; Saltveit, M.E., Jr. Ethylene in Plant Biology; Academic Press: Cambridge, MA, USA, 2012.

83. Morgan, P.W.; Drew, M.C. Ethylene and plant responses to stress. Physiol. Plant. 1997, 100, 620-630. [CrossRef]

84. Kathiresan, A.; Tung, P.; Chinnappa, C.C.; Reid, D.M. gamma-Aminobutyric acid stimulates ethylene biosynthesis in sunflower. Plant Physiol. 1997, 115, 129-135. [CrossRef]

85. Tian, Q.; Zhang, X.; Ramesh, S.; Gilliham, M.; Tyerman, S.D.; Zhang, W.-H. Ethylene negatively regulates aluminium-induced malate efflux from wheat roots and tobacco cells transformed with TaALMT1. J. Exp. Bot. 2014, 65, 2415-2426. [CrossRef] [PubMed]

86. Chevrot, R.; Rosen, R.; Haudecoeur, E.; Cirou, A.; Shelp, B.J.; Ron, E.; Faure, D. GABA controls the level of quorum-sensing signal in Agrobacterium tumefaciens. Proc. Natl. Acad. Sci. USA 2006, 103, 7460-7464. [CrossRef] [PubMed]

87. Bouche, N.; Fait, A.; Zik, M.; Fromm, H. The root-specific glutamate decarboxylase (GAD1) is essential for sustaining GABA levels in Arabidopsis. Plant Mol. Biol. 2004, 55, 315-325. [CrossRef] [PubMed]

88. Lam, H.-M.; Chiu, J.; Hsieh, M.-H.; Meisel, L.; Oliveira, I.C.; Shin, M.; Coruzzi, G. Glutamate-receptor genes in plants. Nature 1998, 396, 125-126. [CrossRef] [PubMed]

89. Demidchik, V.; Shabala, S. Mechanisms of cytosolic calcium elevation in plants: The role of ion channels, calcium extrusion systems and NADPH oxidase-mediated 'ROS-Ca2+ Hub'. Funct. Plant Biol. 2017, 45, 9-27. [CrossRef]

90. Gordeeva, A.; Zvyagilskaya, R.; Labas, Y.A. Cross-talk between reactive oxygen species and calcium in living cells. Biochemistry 2003, 68, 1077-1080.

91. Yuan, F.; Yang, H.; Xue, Y.; Kong, D.; Ye, R.; Li, C.; Zhang, J.; Theprungsirikul, L.; Shrift, T.; Krichilsky, B. OSCA1 mediates osmotic-stress-evoked Ca 2+ increases vital for osmosensing in Arabidopsis. Nature 2014, 514, 367-371. [CrossRef]

92. Shelp, B.J.; Mullen, R.T.; Waller, J.C. Compartmentation of GABA metabolism raises intriguing questions. Trends Plant Sci. 2012, 17, 57-59. [CrossRef] [PubMed] 
93. Su, N.; Wu, Q.; Chen, J.; Shabala, L.; Mithöfer, A.; Wang, H.; Qu, M.; Yu, M.; Cui, J.; Shabala, S. GABA operates upstream of $\mathrm{H}+-\mathrm{ATPase}$ and improves salinity tolerance in Arabidopsis by enabling cytosolic $\mathrm{K}+$ retention and $\mathrm{Na}^{+}$exclusion. J. Exp. Bot. 2019, 70, 6349-6361. [CrossRef] [PubMed]

94. Shi, S.Q.; Shi, Z.; Jiang, Z.P.; Qi, L.W.; Sun, X.M.; Li, C.X.; Liu, J.F.; Xiao, W.F.; Zhang, S.G. Effects of exogenous GABA on gene expression of Caragana intermedia roots under $\mathrm{NaCl}$ stress: Regulatory roles for $\mathrm{H}_{2} \mathrm{O}_{2}$ and ethylene production. Plant Cell Env. 2010, 33, 149-162. [CrossRef]

95. Li, L.; Dou, N.; Zhang, H.; Wu, C. The versatile GABA in plants. Plant Signal. Behav. 2021, 16, 1862565. [CrossRef]

96. Sasaki, T.; Yamamoto, Y.; Ezaki, B.; Katsuhara, M.; Ahn, S.J.; Ryan, P.R.; Delhaize, E.; Matsumoto, H. A wheat gene encoding an aluminum-activated malate transporter. Plant J. 2004, 37, 645-653. [CrossRef] [PubMed]

97. Žárský, V. Signal transduction: GABA receptor found in plants. Nat. Plants 2015, 1, 15115. [CrossRef]

98. Zhang, W.-H.; Ryan, P.R.; Sasaki, T.; Yamamoto, Y.; Sullivan, W.; Tyerman, S.D. Characterization of the TaALMT1 protein as an $\mathrm{Al}^{3+}$-activated anion channel in transformed tobacco (Nicotiana tabacum L.) cells. Plant Cell Physiol. 2008, 49, 1316-1330. [CrossRef]

99. Pineros, M.A.; Cançado, G.M.; Kochian, L.V. Novel properties of the wheat aluminum tolerance organic acid transporter (TaALMT1) revealed by electrophysiological characterization in Xenopus oocytes: Functional and structural implications. Plant Physiol. 2008, 147, 2131-2146. [CrossRef]

100. Meyer, S.; Mumm, P.; Imes, D.; Endler, A.; Weder, B.; Al-Rasheid, K.A.; Geiger, D.; Marten, I.; Martinoia, E.; Hedrich, R. AtALMT12 represents an R-type anion channel required for stomatal movement in Arabidopsis guard cells. Plant J. 2010, 63, 1054-1062. [CrossRef]

101. Palmer, A.J.; Baker, A.; Muench, S.P. The varied functions of aluminium-activated malate transporters-much more than aluminium resistance. Biochem. Soc. Trans. 2016, 44, 856-862.

102. Piñeros, M.A.; Cançado, G.M.; Maron, L.G.; Lyi, S.M.; Menossi, M.; Kochian, L.V. Not all ALMT1-type transporters mediate aluminum-activated organic acid responses: The case of ZmALMT1-an anion-selective transporter. Plant J. 2008, 53, 352-367. [CrossRef]

103. Kovermann, P.; Meyer, S.; Hörtensteiner, S.; Picco, C.; Scholz-Starke, J.; Ravera, S.; Lee, Y.; Martinoia, E. The Arabidopsis vacuolar malate channel is a member of the ALMT family. Plant J. 2007, 52, 1169-1180. [CrossRef] [PubMed]

104. Delhaize, E.; Ryan, P.R. Aluminum toxicity and tolerance in plants. Plant Physiol. 1995, 107, 315. [CrossRef] [PubMed]

105. Ryan, P.; Delhaize, E.; Jones, D. Function and mechanism of organic anion exudation from plant roots. Annu. Rev. Plant Biol. 2001, 52, 527-560. [CrossRef]

106. Barbier-Brygoo, H.; De Angeli, A.; Filleur, S.; Frachisse, J.-M.; Gambale, F.; Thomine, S.; Wege, S. Anion channels/transporters in plants: From molecular bases to regulatory networks. Annu. Rev. Plant Biol. 2011, 62, 25-51. [CrossRef] [PubMed]

107. Ramesh, S.A.; Kamran, M.; Sullivan, W.; Chirkova, L.; Okamoto, M.; Degryse, F.; McLaughlin, M.; Gilliham, M.; Tyerman, S.D. Aluminum-Activated Malate Transporters Can Facilitate GABA Transport. Plant Cell 2018, 30, 1147-1164. [CrossRef]

108. Long, Y.; Tyerman, S.D.; Gilliham, M. Cytosolic GABA inhibits anion transport by wheat ALMT1. New Phytol. 2020, 225, 671-678. [CrossRef] [PubMed]

109. Gilliham, M.; Tyerman, S.D. Linking metabolism to membrane signaling: The GABA-malate connection. Trends Plant Sci. 2016, 21, 295-301. [CrossRef] [PubMed]

110. Shabala, L.; Zhang, J.; Pottosin, I.; Bose, J.; Zhu, M.; Fuglsang, A.T.; Velarde-Buendia, A.; Massart, A.; Hill, C.B.; Roessner, U. Cell-type-specific H+-ATPase activity in root tissues enables $\mathrm{K}+$ retention and mediates acclimation of barley (Hordeum vulgare) to salinity stress. Plant Physiol. 2016, 172, 2445-2458. [CrossRef]

111. Dreyer, I.; Blatt, M.R. What makes a gate? The ins and outs of Kv-like K+ channels in plants. Trends Plant Sci. 2009, 14, 383-390. [CrossRef]

112. Eisenach, C.; Papanatsiou, M.; Hillert, E.K.; Blatt, M.R. Clustering of the K+ channel GORK of A rabidopsis parallels its gating by extracellular $\mathrm{K}^{+}$. Plant J. 2014, 78, 203-214. [CrossRef] [PubMed]

113. Adem, G.D.; Chen, G.; Shabala, L.; Chen, Z.-H.; Shabala, S. GORK Channel: A Master Switch of Plant Metabolism? Trends Plant Sci. 2020, 25, 434-445. [CrossRef]

114. Felle, H.H. pH regulation in anoxic plants. Ann. Bot. 2005, 96, 519-532. [CrossRef] [PubMed]

115. Shabala, S.; Bose, J.; Fuglsang, A.T.; Pottosin, I. On a quest for stress tolerance genes: Membrane transporters in sensing and adapting to hostile soils. J. Exp. Bot. 2016, 67, 1015-1031. [CrossRef] 